\title{
ВАЛЬДОРФСЬКА ШКОЛА — СВІТ ПРАЦІ
}

\section{Бужин О. В.}

здобувач третього (освітньо-наукового) рівня вищої освіти кафедри освітології та інноваційної педагогіки, Харківський національний педагогічний університет імені Г.С. Сковороди, м. Харків, Україна

Розглянуто роль і особливості трудового навчання у вальдорфській школі та значущість уроків прачі протягом 12-річного навчання. 3'ясовано важливість уроків праці у формуванні гармонійно розвиненоі особистості, розвитку інтелектуальної, емочійно-почуттєвої та вольової сфер.

Ключові слова: вальдорфська школа, трудове навчання, розвиток особистості.

The role and features of labor training in the Waldorf school and the importance of labor lessons during 12-year training are considered. The importance of labor lessons in the formation of a harmoniously developed personality, the development of intellectual, emotional and volitional spheres is clarified.

Key words: Waldorf school, labor training, personality development

Одним із пріоритетних завдань сучасної школи є всебічний розвиток особистості, ії мислення, емоційно-почуттєвої та вольової сфер. Для розв'язання цих завдань важливим є залучення кращого світового досвіду, зокрема досвіду вальдорфської школи.

Із перших років існування вальдорфської школи винятково важливе місце для гармонійного розвитку дитини відводилося практичній діяльності, адже першочерговим завданням уроків ручної праці є розвиток тонкої моторики рук, що стимулює розвиток основних пізнавальних процесів (мислення, уваги, мовлення); набуття вмінь і навичок у різних галузях людської діяльності; розвиток емоційно-вольової сфери.

Тому заняття рукоділлям та ремеслами впродовж усього 12-річного процесу вальдорфської освіти мають таку же значущість, як і вивчення академічних дисциплін.

Уроки рукоділля розпочинаються з роботи з м'яким матеріалом: діти вчаться в'язати, шити, валяти вовну. Варто зазначити, що у вальдорфській школі всі види діяльності виконують як дівчата, так і хлопчики. 
Розділ III. Історичні та порівняльні аспекти в теорії і практиці духовно-інтелектуального виховання й навчання

Уже $з$ першого класу діти вчаться в'язати спицями невеликі речі (маленькі ляльки і тварини, кухонні прихватки), у другому класі набувають навичок в'язання гачком (учні виготовляють серветки,сіткимішечки для взуття і м'ячів тощо). У четвертому класі учні вчаться вишивати хрестиком і шити вручну прості речі, наприклад, подушечки для голок, гаманці для приладдя з рукоділля. [2, с. 171]. Пізніше, у шостому класі, діти шиють ляльок та одяг для них, у сьомому класі власний одяг (сорочки, брюки), а вже у восьмому класі набувають навичок шиття на швейній машинці [2, с. 458]. Учні старших класів займаються прядінням і ткацтвом: за власними ескізами виготовляють подушки, ковдри, килими. Окрім того, відповідно до фізичного розвитку дітей (відбувається зміцнення внутрішньої стійкості та сили) вони займаються лозоплетінням — плетуть корзини, гамаки, виготовляють капелюхи.

Особливе місце в трудовому навчанні посідає напрямок «Ремесло». Починаючи 33 класу, під час вивчення епохи «Давні ремесла» 3 предмету «Навколишній світ. Природознавство», учні знайомляться 3 традиційними народними ремеслами, знаряддями праці, різноманітними виробничими процесами (вирощування хліба, будівництво) [1, с. 238].

У середній школі, коли повністю закінчується формування зап'ястних кісток, діти починають працювати з твердим матеріалом - деревом. Учні знайомляться з різними видами інструментів, виконують деякі столярні роботи, наприклад, пиляння, довблення, стругання, обпилювання деревини рашпілем або напилком, зачищування наждачним папером. Опановуючи технології роботи з деревиною школярі виготовляють різноманітні вироби: рамку для картини, підноси для хліба або фруктів, рухомі іграшки, невеликі меблі тощо [1, с. 239].

У старшій школі, починаючи 3 дев’ятого класу, діти починають працювати з металами: спочатку з міддю, а потім із залізом. На перших етапах учні знайомляться з матеріалом і його властивостями, з інструментами, а потім вчаться робити розмітку виробу, вирізати деталі слюсарними ножицями, вибивати заглиблення, вирівнювати поверхні, паяти вироби, зачищувати місця з'єднання деталей виробу. Під час роботи з металами старшокласники виготовляють браслети, кулони, чаші, підсвічники, підставки для книг, лампади. 
Кожна школа має свої майстерні - столярні, слюсарні, де учні старших класів виготовляють меблі для школи, сходові прольоти тощо. Ті види діяльності, які учні не можуть осягнути в шкільних майстернях, вони вивчають на підприємствах, на яких опановують сучасні промислові та аграрні технології [1, с. 239].

3 огляду на це, можна відзначити важливість уроків праці у формуванні гармонійно розвиненої особистості. Такі заняття дають учням теоретичні та практичні знання про роботу з різними матеріалами, розвивають мислення, формують трудові навички, необхідні для життя, позитивне ставлення до праці, рішучість, самостійність, уміння доводи справу до кінця.

\section{Список використаних джерел:}

1. Ионова Е. Н. Вальдорфская педагогика : теоретико-методологические аспекты. Харьков : Бизнес Информ, 1997. 300 с.

2. Програми для вальдорфських шкіл України: 1-9 кл. / МОН України, департамент заг. серед. та дошк. освіти, Ін-т інновац. технологій та змісту освіти, Міжнародна асоціація вальдорфської педагогіки у Центральній та Східній Європі, Асоціація вальдорфських ініціатив України. Київ : Генеза, 20209. 512 с. 